\title{
Biodiversity of Oenological Lactic Acid Bacteria: Species- and Strain-Dependent Plus/Minus Effects on Wine Quality and Safety
}

\author{
Vittorio Capozzi ${ }^{1,+}\left(\mathbb{0}\right.$, Maria Tufariello ${ }^{2,+} \oplus$, Nicola De Simone ${ }^{3}$, Mariagiovanna Fragasso ${ }^{3}$ \\ and Francesco Grieco $2, *$ (i) \\ 1 National Research Council-Institute of Sciences of Food Production (ISPA) c/o CS-DAT, \\ Via Michele Protano, 71121 Foggia, Italy; vittorio.capozzi@ispa.cnr.it \\ 2 National Research Council-Institute of Sciences of Food Production (ISPA), Via Prov.le, Lecce-Monteroni, \\ 73100 Lecce, Italy; maria.tufariello@ispa.cnr.it \\ 3 Department of Agriculture, Food, Natural Resources, and Engineering, University of Foggia, \\ 71121 Foggia, Italy; nicola_desimone.552001@unifg.it (N.D.S.); mariagiovanna.fragasso@gmail.com (M.F.) \\ * Correspondence: francesco.grieco@ispa.cnr.it; Tel.: +39-0832422612 \\ + These authors contributed equally to this work.
}

Citation: Capozzi, V.; Tufariello, M.; De Simone, N.; Fragasso, M.; Grieco, F. Biodiversity of Oenological Lactic Acid Bacteria: Species- and Strain-Dependent Plus/Minus Effects on Wine Quality and Safety.

Fermentation 2021, 7, 24. https:// doi.org/10.3390/fermentation7010024

Received: 30 December 2020

Accepted: 12 February 2021

Published: 17 February 2021

Publisher's Note: MDPI stays neutral with regard to jurisdictional claims in published maps and institutional affiliations.

Copyright: (c) 2021 by the authors. Licensee MDPI, Basel, Switzerland. This article is an open access article distributed under the terms and conditions of the Creative Commons Attribution (CC BY) license (https:/ / creativecommons.org/licenses/by/ $4.0 /)$.

\begin{abstract}
Winemaking depends on several elaborate biochemical processes that see as protagonist either yeasts or lactic acid bacteria (LAB) of oenological interest. In particular, LAB have a fundamental role in determining the quality chemical and aromatic properties of wine. They are essential not only for malic acid conversion, but also for producing several desired by-products due to their important enzymatic activities that can release volatile aromatic compounds during malolactic fermentation (e.g., esters, carbonyl compounds, thiols, monoterpenes). In addition, LAB in oenology can act as bioprotectors and reduce the content of undesired compounds. On the other hand, LAB can affect wine consumers' health, as they can produce harmful compounds such as biogenic amines and ethyl carbamate under certain conditions during fermentation. Several of these positive and negative properties are species- and strain-dependent characteristics. This review focuses on these aspects, summarising the current state of knowledge on LAB's oenological diversity, and highlighting their influence on the final product's quality and safety. All our reported information is of high interest in searching new candidate strains to design starter cultures, microbial resources for traditional/typical products, and green solutions in winemaking. Due to the continuous interest in LAB as oenological bioresources, we also underline the importance of inoculation timing. The considerable variability among LAB species/strains associated with spontaneous consortia and the continuous advances in the characterisation of new species/strains of interest for applications in the wine sector suggest that the exploitation of biodiversity belonging to this heterogeneous group of bacteria is still rising.
\end{abstract}

Keywords: malolactic fermentation; lactic acid bacteria; malolactic bacteria; Oenococcus oeni; Lactiplantibacillus plantarum; wine; aroma; biogenic amines; lactobacilli; biocontrol

\section{LAB in Oenology: Introductory Aspects and Biodiversity}

During the winemaking process, lactic acid bacteria (LAB) promote the decarboxylation of L-malic acid to L-lactic acid, which is denoted as malolactic fermentation (MLF) [1]. This biological process occurs at the end of the alcoholic fermentation (AF), the principal phase in winemaking, which is conducted by yeasts (mainly belonging to the Saccharomyces genus, but together, in some cases, with selected non-Saccharomyces strains) [2-4]. MLF is required for aged red wines and some young red, white, and base sparkling wines, since it supplies microbiological stabilisation by reducing the nutrients in wine and lowers the acidity of the final product [5,6]. Specific management of microbial resources inoculated to promote desired biochemisms (e.g., co-inoculation), can favour a simultaneous progression of AF and MLF $[7,8]$. 
MLF enhances wine flavour and aroma complexity by freeing relevant amounts of carbonyl compounds, such as diacetyl (2,3-butanedione), which contributes to a wine's buttery flavour [9]. Moreover, LAB species have demonstrated an ability to promote several biochemical modifications of wine able to enhance its aroma, such as the release of volatile thiols from precursor compounds, methionine metabolism, glycosidases, and esterase activities [10-12]. However, during winemaking, the MLF dynamics are often unpredictable, and it is problematic to monitor or manage. Spontaneous MLF may affect wine quality, since the production of bacteria-derived off-flavour molecules (such as volatile phenols and acetic acid) and compounds dangerous to consumer health, i.e., biogenic amines (BAs) and ethyl carbamate. Thus, it is necessary to exert the microbiological control of this biochemical process throughout the winemaking process to guarantee the final product's quality and safety [13]. A composite microbial consortium is implicated in the winemaking process, comprising yeast, bacteria, fungi, and viruses [14-16]. Concerning $\mathrm{LAB}$, they are indeed present on both grape skins and cellar environment equipment [17], but the operators can directly inoculate them by the addition of selected starter cultures [18].

$\mathrm{LAB}$, microaerophiles, and Gram-positive bacteria specifically produce lactic acid as a primary metabolite of glucose catabolism [19]. Consistent with their glucose catabolic activity, they can be distributed into two groups: bacteria that ferment glucose with lactic acid as the main by-product (homofermentative), and the others that produce ethanol, carbon dioxide, and lactic and acetic acid after glucose fermentation (heterofermentative). The most common LAB isolated from musts and wine are oenoccocci, lactobacilli and pediococci (Table 1).

Table 1. Species of selected lactic acid bacteria found in association with raw materials in representative phases of winemaking (grape harvest, must alcoholic fermentation, wine malolactic fermentation), according to selected studies [20-25].

\begin{tabular}{|c|c|c|}
\hline Grape and Harvest & Must and AF & Wine and MLF \\
\hline $\begin{array}{c}\text { Oenococcus oeni }(0-10 \%) \\
\text { Limosilactobacillus alvi } \\
\text { Levilactobacillus brevis } \\
\text { Limosilactobacillus frumenti } \\
\text { Liquorilactobacillus mali } \\
\text { Apilactobacillus kunkeei } \\
\text { Fructilactobacillus lindneri } \\
\text { Fructilactobacillus sanfranciscensis } \\
\text { Lentilactobacillus kefiri } \\
\text { Lactococcus lactis } \\
\text { Enterococcus faecium } \\
\text { Enterococcus avium } \\
\text { Enterococcus durans } \\
\text { Enterococcus hermanniensis } \\
\text { Leuconostoc mesenteroides } \\
\text { Pediococcus damnosus } \\
\text { Pediococcus parvalus } \\
\text { Weissella paramesenteroides }\end{array}$ & $\begin{array}{l}\text { Oenococcus oeni (80-100\%) } \\
\text { Lactiplantibacillus plantarum } \\
\text { Lentilactobacillus hilgardii } \\
\text { Lentilactobacillus buchneri } \\
\text { Lentilactobacillus diolivorans } \\
\text { Lacticaseibacillus casei } \\
\text { Latilactobacillus curvatus } \\
\text { Limosilactobacillus alvi } \\
\text { Levilactobacillus brevis } \\
\text { Limosilactobacillus frumenti } \\
\text { Secundilactobacillus collinoides } \\
\text { Lacticaseibacillus paracasei } \\
\text { Lactiplantibacillus pentosus } \\
\text { Liquorilactobacillus mali } \\
\text { Fructilactobacillus lindneri } \\
\text { Fructilactobacillus fructivorans } \\
\text { Lactobacillus delbrueckii } \\
\text { Lactococcus lactis } \\
\text { Leuconostoc citreum } \\
\text { Leuconostoc fructosum } \\
\text { Leuconostoc mesenteroides } \\
\text { Enterococcus faecium } \\
\text { Pediococcus damnosus } \\
\text { Pediococcus parvalus } \\
\text { Weissella paramesenteroides }\end{array}$ & $\begin{array}{c}\text { Oenococcus oeni } \\
\text { Lactiplantibacillus plantarum } \\
\text { Lentilactobacillus hilgardii } \\
\text { Levilactobacillus brevis } \\
\text { Fructilactobacillus lindneri } \\
\text { Limosilactobacillus frumenti } \\
\text { Lactococcus sp. } \\
\text { Pediococcus parvalus }\end{array}$ \\
\hline
\end{tabular}

Note: AF, alcoholic fermentation; MLF, malolactic fermentation.

The O. oeni species has ellipsoidal-to-spherical cells typically present in pairs or short chains. It is an asporogenous and nonmotile bacteria with an optimal growth range between $\mathrm{pH} 4.8-5.5$ and $20-30^{\circ} \mathrm{C}$. The $O$. oeni population typically raises during the $\mathrm{AF}$, and it often becomes the only species found in wine at the end of MLF $[26,27]$. O. oeni is the principal 
LAB species of choice for winemakers because it can tolerate the harsh environment for bacterial survival after the completion of the AF [28]. Three different decarboxylation pathways are responsible for the conversion of L-malic acid to L-lactic acid (Figure 1).

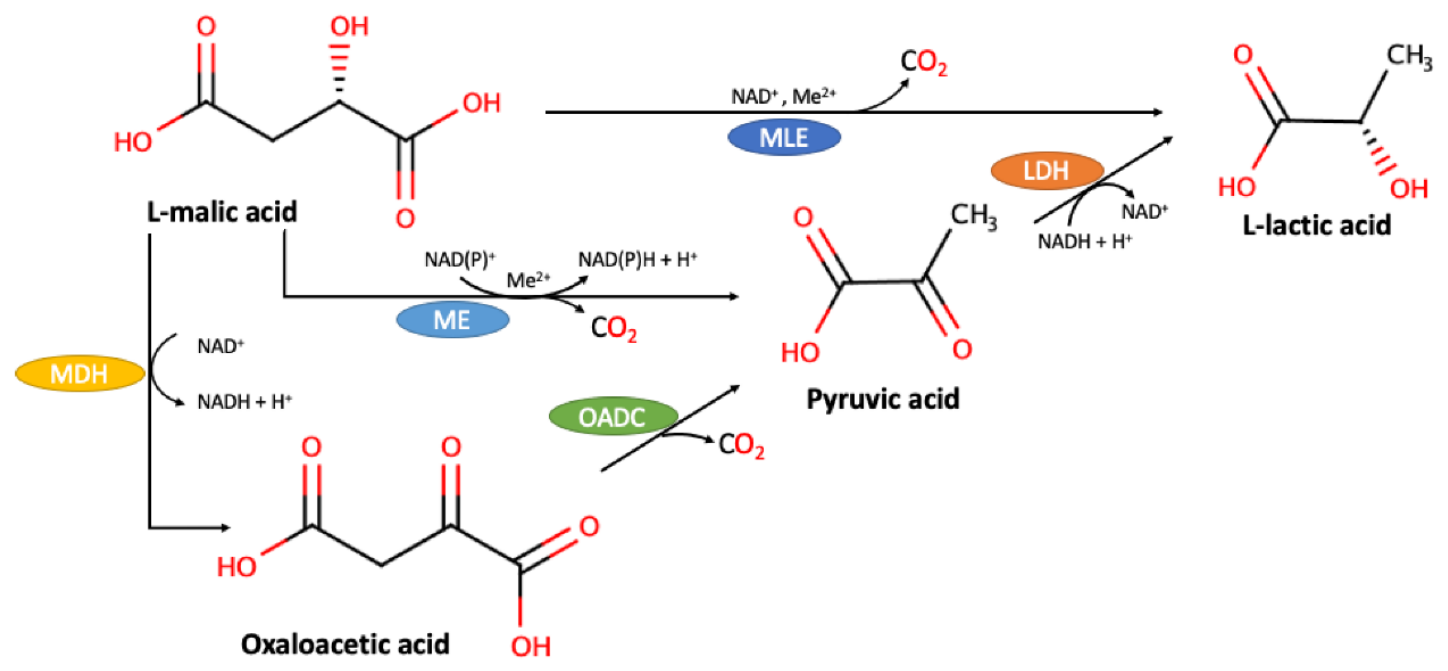

Figure 1. Possible biochemical routes responsible for the decarboxylation of L-malic acid to L-lactic acid. Image reproduced from Acevedo et al. [29]. MDH, malate dehydrogenase; ME, malic enzyme; MLE, malolactic enzyme; OADC, oxaloacetate decarboxylase; LDH, lactate dehydrogenase.

Lactobacilli have elongated shapes with rod-like forms, and they are facultative heterofermentative. These bacteria's taxonomy has been recently rewritten using a holistic approach that considered ecological, genetic, metabolic, and physiological criteria [30]. The previously genus denoted as Lactobacillus has been reorganised into 25 novel genera, and the previous Lactobacillaceae and Leuconostocaceae families have been merged to form the new Lactobacillaceae family [30]. Lactobacilli have shown that they successfully withstand winemaking conditions and possess many advantageous properties that make them appropriate for MLF management [31,32]. Besides their malolactic activity, these LAB detain complex secondary metabolisms that can positively influence a wine's final aroma and flavour, including synthesis or catalysis of citrates, amino acids, polysaccharides, aldehydes, and esters [33,34]. In particular, Lactiplantibacillus plantarum strains can promote MLF under high $\mathrm{pH}$ conditions, avoiding acetic acid synthesis due to their facultative heterofermentative features, and modifying wine aromas because of a more composite enzymatic profile when compared to O. oeni [31,32]. Together with the properties mentioned above, the significant oenological features of $L$. plantarum, i.e., the elevated tolerance to high both ethanol and $\mathrm{SO}_{2}$ concentration and to $\mathrm{pH}$ conditions, make strains belonging to this species the source of the novel generation of MLF starter cultures [18,25,31].

Pediococcus damnosus, P. parvulus, P. pentosaceus, and P. inopinatus belong to the genus Pediococcus that has oenological importance [35]. They have a spherical or ellipsoidal form and possess a homofermentative glucose metabolism. Pediococcus spp. are commonly considered spoilage bacteria in wine because some strains can cause viscosity in wine due to their production of exopolysaccharides, produce a high amount of acetic acid, and synthesise biogenic amines [36]. However, species/strains belonging to the Pediococcus genus can positively influence the production of volatile compounds by synthesising a large number of secreted enzymes [36,37].

The huge microbial diversity of LAB associated with natural consortia (Table 1), together with the evolution of L. plantarum and pediococci significance in oenology, underlines the continuous interest in exploring the potential role of bacterial biodiversity in wine.

It is interesting to point out that for numerous LAB strains worldwide that are isolated from the oenological environment, their complete genome has been already sequenced 
(Table 2), promoting knowledge improvements, molecular advances, and the application of "omics" approaches.

Table 2. Information about literature on the complete genome sequences of wine LAB strains.

\begin{tabular}{|c|c|c|}
\hline Strains & Place of isolation & Reference \\
\hline Oenococcus oeni PSU-1 & United States of America & {$[38]$} \\
\hline $\begin{array}{l}11 \text { O. oeni strains ( } 6 \text { commercial and } \\
5 \text { environmental isolates) }\end{array}$ & $\begin{array}{c}\text { Commercial starter cultures } \\
\text { and Australia }\end{array}$ & [39] \\
\hline Oепососси оепi OM27 & Italy & {$[40]$} \\
\hline 5 O. oeni strains isolated from the same terroir & Italy & {$[41]$} \\
\hline 14 O. oeni strains isolated from different wines & France & [42] \\
\hline 28 O. oeni strains isolated from different wines & $\begin{array}{l}\text { Several countries (mainly } \\
\text { from France and Australia) }\end{array}$ & [43] \\
\hline Oenococcus oeni $\mathrm{X} 2 \mathrm{~L}$ & Argentina & [44] \\
\hline About 135 O. oeni wine strains & $\begin{array}{l}\text { Several countries (mainly } \\
\text { from France and Australia) }\end{array}$ & [45] \\
\hline Oenococcus oeni UNQOe19 & Patagonia & [46] \\
\hline Lactiplantibacillus plantarum Lp90 & Italy & [47] \\
\hline Lactiplantibacillus plantarum XJ25 & China & [48] \\
\hline Lactiplantibacillus plantarum UNQLp 11 & Patagonia & [49] \\
\hline
\end{tabular}

\section{Impact of Wine Environment on LAB Metabolisms}

After the ending of the AF, the concentration of LAB populations does not usually change for 10 to 15 days, since bacterial multiplication is likely to be impaired by the residual yeast metabolic activity. Then, the LAB initiate to grow, and MLF occurs when the bacterial concentration in wine roughly corresponds to $10^{6} \mathrm{CFU} / \mathrm{mL}$. However, the physical and chemical factors of wine that can affect LAB's malolactic performances are numerous [28]. Indeed, bacterial multiplication is enhanced by sulfur dioxide and ethanol concentrations lower than $20 \mathrm{mg} / \mathrm{L}$ and $14 \%(\mathrm{v} / 100 \mathrm{~mL})$, respectively, relatively high $\mathrm{pH}$ values (>3.5), and a wine temperature ranging from 19 to $26^{\circ} \mathrm{C}$. The above stress factors possess different cellular targets, and they can affect different bacterial metabolisms, and thus are able to exert strong effects on cellular growth and viability [50]. Sulfur dioxide $\left(\mathrm{SO}_{2}\right)$ is routinely added to must and wines during the winemaking process because its antimicrobial and antioxidant action preserves the chemical and microbiological quality of wine. $\mathrm{SO}_{2}$ is detectable in wine in both a free and bonded form: the former is available and able to carry out its protective action, whereas the latter cannot play an active role since it is bonded to several wine-related compounds (acids, anthocyanins and acetaldehyde). Even though LAB can exert cellular mechanisms for adaptation to $\mathrm{SO}_{2}$ [51], high additions (>20 mg/mL) of $\mathrm{SO}_{2}$ can inhibit the bacterial malolactic performances, thus suggesting that a strict monitoring of the additive concentration is required during the MLF. Ethanol concentrations over $14 \%(\mathrm{v} / 100 \mathrm{~mL})$ can affect growth and metabolism of LABs and this toxic action is enhanced by the increase of temperature and lowering of $\mathrm{pH}[52,53]$. Indeed, $\mathrm{pH}$ and alcohol content of wine have demonstrated that they are fundamental oenological factors to regulate bacterial viability and, subsequently, their malate-degrading ability $[53,54]$. High ethanol concentrations also impair cellular mechanisms devoted to maintaining $\mathrm{pH}$ homeostasis, increasing the passive proton flux into bacteria [55]. However, LAB's capacity to survive at elevated ethanol concentrations is a strain-dependent property among different species [25]. Temperature is a parameter that disturbs the growth rate and, in particular, the length of the lag phase of LAB [56]. Previous microbiological observation emphasised the stress exercised by high temperatures on LAB metabolism [57]. The authors indicated that temperatures above $30^{\circ} \mathrm{C}$ prejudiced bacteria's capacity (in particular, O. oeni) 
to degrade the malic acid and potentially enhanced acetic acid production. These findings have been recently confirmed by Guzzon and coworkers [58]. They showed that the L. plantarum strain more efficiently carried out the MLF compared to O. oeni, since the latter species was inhibited by a high fermentation temperature with subsequent incomplete malic acid degradation.

\section{Plus Effects: Influence of MLF on Wine Organoleptic Properties, Bioprotection and the Removal of Undesired Compounds}

In recent years, the metabolism of lactic bacteria that carry out MLF has been thoroughly investigated $[25,59,60]$. In addition to the decarboxylation of malic in lactic acid, which is the principal outcome of MLF, this biological process also produces a significant number of metabolic by-products. Most of these compounds are strain-specific, and they can positively modulate the volatile aroma profile and aroma perception of a wine [61,62]. In addition to the benefits for sensory quality, other important targets regarding the innovative use of LAB in oenology, are the biocontrol of undesired microbes (e.g., spoilers) and the degradation of toxic compounds. In fact, LAB have been proposed as part of potential sustainable solutions to enhance wine safety and reduce relevant economic losses.

\subsection{Esters}

Esters are secondary or tertiary compounds that considerably contribute to a wine's aromatic profile. They can be synthesised by yeast and bacteria throughout the AF and MLF, and their qualitative and quantitative profile can be modified by wine ageing $[63,64]$. Esters are formed through the esterification process or via ester hydrolysis [64]. LAB's contribution to the ester detectable in wine has been underlined by several investigations $[12,63]$. LAB's ability to affect or enhance the amount of esters in wine is strain-specific, and it is modulated by the MLF inoculation procedure $[9,65,66]$. In general, MLF is associated with increases in ethyl fatty acid esters' concentration, such as ethyl acetate, ethyl lactate, ethyl octanoate, and ethyl hexanoate $[61,67]$. This class of volatile molecules is responsible for the desired fruity aroma of wines. The LAB esterases have been recently investigated $[17,68]$. Costello and coworkers [69] have shown that O. oeni is able to produce relevant amounts of ethyl octanoate, propyl octanoate, and ethyl hexanoate due to the significant activity of intracellular esterases throughout the fermentation process. L. plantarum strains have been recently proposed as malolactic starters, since this species is a significant source of esterase enzymes [70]. In fact, Lerm et al. [18] highlighted that L. plantarum strains, due to their enzymatic activity, can modulate wines' volatile profiles more efficiently than $O$. oeni. These results have been further confirmed by investigating lactobacilli isolated from South African wines [33].

\subsection{Carbonyl Compounds}

Acetaldehyde is the main carbonyl compound present in wine that can add to wines' aromatic profile, such as notes of "nutty" and "bruised apple." Lactic bacteria can metabolise acetaldehyde when linked to sulfur dioxide, thus increasing the final concentration of this inhibitory compound [71]. However, the decrease in the acetaldehyde concentration caused by LAB can influence the colour and modulate the final wine's sensorial impression [72]. One of the major aroma compounds associated with LAB is diacetyl (2,3-butanedione), which originates from citrate fermentation and gives buttery and nutty notes to wines [59]. The citric acid is enzymatically transformed into pyruvate that can be converted to acetolactic acid. The decarboxylation of this last compound produces 2,3butanediol and acetoin and their the oxidation gives rise to diacetyl during the occurrence of the MLF. When found in the range of $1-4 \mathrm{mg} / \mathrm{L}$, diacetyl usually gives a wine positive aromatic notes, whereas when it is detected at concentrations higher than $5-7 \mathrm{mg} / \mathrm{L}$, it is considered an undesired spoilage feature. Consequently, winemakers modulate diacetyl concentrations in order to enhance a wine's aroma through microbiological management during the winemaking process $[73,74]$. However, a number of other different factors, such 
as the wine type, as well as oxygen and sulfur dioxide concentrations, determines the final concentration of diacetyl in wine.

\subsection{Thiols}

Volatile thiols are compounds of specific relevance to the composition of the varietal character [75]. In fact, they give tropical fruit notes to wine obtained from Sauvignon Blanc, Riesling, Cabernet Sauvignon, and Merlot grapes [76]. These molecules do not exist in grape juice, and are released during fermentative processes. However, wine yeasts do not synthesise volatile thiols de novo, but they promote thiol release from its precursor. Recently, Takase and coworkers [11] demonstrated that L. plantarum carry out the cleavage of 3-Sulfanylhexan-1-ol (3SH) from its precursor 3SH from S-3-(hexan-1-ol)-1-cysteine (3SH-S-cys) and S-3-(hexan-1-ol)-1-cysteinylglycine (3SH-S-cysgly), which contribute to varietal aromatic profiles, with notes of grapefruit and passionfruit. Even though the enzymes for the pathway and the specific enzyme in charge of this conversion have not yet been characterized, the above findings indicate that MLF guided by enzymatically active lactobacilli can improve the varietal aroma of produced wines. However, other volatile sulfur compounds, such as methanethiol, methionol, and dimethyl disulfide, when present in the opportune amounts, can enhance a wine's bouquet and sensorial quality [77].

\subsection{Monoterpenes}

The varietal compounds specific to each grape variety have great importance in the composition of the wine's aromatic profile. They can be present in the berry as free volatile molecules or mainly linked to sugars, these being the aroma precursors. The glycol-conjugates are not odorous and volatile, but they are a source of odorant molecules in wines, with a varietal, microbial, or technological origin. Volatile monoterpenes are released at the early stage of winemaking, directly or after the adding of oenological enzymes [78]. The microbial conversion from the precursors of free volatile monoterpenes necessitate the secretion of active $\beta$-glucosidase (in the case of monoglycosides) or exoglycosydases (active on disaccharides) [79]. Numerous investigations have demonstrated that $O$. oeni possesses a detectable $\beta$-glucosidase activity $[80,81]$. Recently, Michlmayr and coworkers [82] identified numerous LAB glycosidases with potential in the release of grape-derived aroma precursors. The authors described a glucosidase and an arabinosidase from $O$. oeni able to produce high concentrations of monoterpenes. The above evidence highlights that these bacterial enzymes can play an important role in the hydrolysis of aroma precursors during malolactic fermentation, since they were active in grape must and displayed wide substrate specificities. Hydrolytic enzymatic activity has also been detected in other oenological LAB genera, i.e., lactobacilli and pediococci [83]. Other authors have compared several malolactic starter cultures' performances in the releasing of specific volatile odorant molecules [84]. Levilactobacillus brevis and Lacticaseibacillus casei strains demonstrated that they were differentially capable of enhancing the amount of C13norisoprenoides and monoterpenes in wine after completing the MLF. Recent investigations have indicated that several L. plantarum strains show a peculiar enzymatic profile when compared to other $\mathrm{LAB}$, thus proposing that this species can perform a significant action in contributing to a wine's aromatic profile $[10,18]$.

\subsection{Degradation of Toxic Compounds}

Two main classes of contaminants of microbial origin can affect wine safety: mycotoxins (mainly ochratoxin A, OTA) and BAs [85].

Mycotoxins are secondary metabolites produced by filamentous fungi, with relevant carcinogenic, teratogenic, nephrotoxic, and hepatotoxic properties [86]. Ochratoxin A, produced on grape berries by several Aspergillus and Penicillium species, is the most frequently mycotoxin found in wine samples [87]. Several phases in winemaking can influence OTA reduction, including microbes. Both alcoholic and malolactic fermentation can reduce OTA in wine [88]. In effect, selected yeasts and LAB demonstrated this capability [89,90]. 
Del Prete et al. [91] showed OTA removal by five LAB species of interest in wines, suggesting a cell-binding activity [91]. In O. oeni, heat-inactivated cells also were capable of removing OTA in synthetic media [92]. Abrunhosa et al. [93] highlighted the OTA biodegradation by $P$. parvulus strains isolated from Douro wines, as well as in grape must.

BAs are low molecular weight, organic bases, frequently occurring in wine, in which up to 25 different amines could be detected [94]. Although they can be found in wine in very low amounts compared to other fermented foods, BAs can exert a dangerous effect on consumer health because the ethanol can strengthen their noxious action by affecting human action on amine-oxidases accountable for their inactivation [95]. Enzymatic removal of BAs may represent a functional and cost-effective method to eliminate these harmful compounds in wine production. Capozzi and coworkers [96], during the physiological characterization of a L. plantarum population, selected two strains capable of degrading tyramine and putrescine. Callejón and collaborators [97] also identified new BAs-degrading activities of $\mathrm{LAB}$ in wine. The authors studied the enzymatic activities in charge of BAs degradation in 76 lactobacilli, pediococci, and enterococci strains isolated from wine. The enzymes accountable for BAs conversion were identified as multicopper oxidases, were isolated and purified from L. plantarum and P. acidilactici strains. Other lactobacilli were recently described as capable of BAs degradation, such as Latilactobacillus curvatus G-1, L. plantarum CAU3823, and L. plantarum PP02 [98,99]. Taken together, the above results indicate the possible use of wine L. plantarum strains as candidates for the design of starter cultures that can degrade biogenic amines during MLF.

\subsection{Bioprotection}

One emerging trait of lactic acid bacteria on grapes and wine is their potential in bioprotection [100]. The reduction of the chemical intake in wine, from the farm to the fork (from grape cultivation up to winemaking) is rising due to increasing consumer concerns about the toxicological problems of its residues [101] and the emerging evidence of undesired side-effects associated with fermentative performances [102]. This has led producers and researchers to orientate toward more sustainable and eco-friendly approaches. In this light, the selection of microbial strains with potential as bioprotective cultures and/or biological control agents is an emerging trait that is still poorly explored among lactic acid bacteria isolated from grapevine and wine environments [103]. In fact, LAB were already described as promising bioprotective cultures in other food supplies $[104,105]$. They produce a wide range of active antimicrobial compounds, such as organic acids, hydrogen peroxide, fatty acids, acetoin, diacetyl, cyclic dipeptides, and bacteriocins [106-108]. In the grape sector, these microbes could be used for in-field applications and post-harvest diseases, as well as during wine fermentation. In particular, L. plantarum strains have been proposed for the biocontrol of the filamentous fungus Botrytis cinerea, the microorganism responsible for grey mold formation and the main grape spoiler in both pre- and post-harvest conditions [109], as several strains have shown a strong competition and a rapid colonisation of wound space in other fruit crops [110-112]. In winemaking, LAB ensure a rapid implantation of malolactic fermentations when used as starter cultures, thus limiting the residual nutrients for the microorganisms that cause wine spoilage, such as Brettanomyces bruxellensis [113], which produce detrimental volatile compounds that affect the organoleptic quality of the final product, leading to important economic losses [114]. Besides, malolactic strains (belonging to both O. oeni and L. plantarum species) co-inoculated with yeasts demonstrated a potential in enhancing bioprotection $[115,116]$. In this light, $\mathrm{LAB}$ could be a concrete alternative to synthetic protectants, including sulfur dioxide [116].

\section{Minus Effects: Production of Off-Flavours and Other Undesired Compounds}

As described in the last paragraph, selected LAB can enhance global quality in oenological production. However, some species/strains belonging to the heterogeneous group of LAB can also depreciate wines, with substantial economic losses and/or possible undesired consequences for human health. 


\subsection{Production of Off-Flavours by Lactic Acid Bacteria}

Numerous secondary compounds synthesised by lactic acid bacteria can affect a wine's sensorial profile, such as volatile phenols, and N- heterocyclic and sulfur volatile compounds [72]. Several phenolic compounds are present in wine; in particular, hydroxycinnamic acids (caffeic, ferulic, and p-coumaric acids) can be a substrate for LAB-mediated enzymatic conversions [117]. The fertaric, cutaric, and caftaric esterified forms of hydroxycinnamic acids can be released into wine due to the cinnamoyl esterase activities promoted by bacterial enzymes. Phenolic acids can be decarboxylated into 4 -vinyl derivatives and then converted to 4-ethyl derivatives, two classes associated with undesired odorous properties described as "wet dog," "sweaty horse," and "band-aid" [113]. Different investigations have described numerous LAB species' ability to synthesise these detrimental volatile phenols during the vinification process. Couto and collaborators [118] tested the ability of 35 strains of lactic acid bacteria belonging to 20 different species in converting phenolic acids into the corresponding volatile phenols. The reduction stage of the above pathway was detected in L. brevis, L. collinoides and L. plantarum. In contrast, strains belonging to the genus Pediococcus demonstrated the production of 4-vinylphenol but not 4-ethylphenol from p-coumaric acid. O. oeni and L. mesenteroides strains were unable to produce p-coumaric acid derivatives. LAB's capacity to carry out the conversion of volatile phenols in wine has been investigated by applying a novel molecular method able to identify strains that have this ability. The obtained data indicated that L. plantarum strains produced the corresponding vinyl and ethyl derivatives from hydroxycinnamic acids, whereas L. brevis and P. pentosaceus strains only produced the vinyl ones. A recent study confirmed the above results, indicating that all the species belonging to the L. plantarum group are genetically able to produce ethylphenol from vinylphenol [119]. Indeed, the authors highlighted the possible significance of lactic acid bacteria in volatile-phenol spoilage of wine after showing a faster ethylphenol synthesis by these bacteria than by yeasts.

The production of detrimental flavours in wine has been associated with the LAB catabolism of lysine and ornithine, which implicates the formation of numerous very strong and smelly nitrogen-heterocycle "mousy" compounds [120]. These compounds are detected on the back portion of the buccal region as a persistent aftertaste reminiscent of a mouse cage. O. oeni, Leuconostoc mesenteroides, and some lactobacilli can produce three nitrogen-heterocycle compounds relevant at the sensorial level, i.e., 2-ethyltetrahydropyridine (ETPY), 2-acetyl-1-pyrroline (ACPY), and 2-acetyltetrahydropyridine (ACTPY) [120]. High $\mathrm{pH}$ levels (>3.5) or low sulfur dioxide concentration during the winemaking process are likely to promote the growth of heterofermentative lactobacilli and pediococci strains capable of synthesizing the above-mentioned nitrogen-heterocycle compounds. However, very little is known about this defect's physiological basis and its effective consequence on wine quality [121].

Volatile sulfur compounds are produced during the MLF by the bacterial metabolism that utilises cysteine and methionine as substrate, these being the two sulfur-containing amino acids. O. oeni and lactobacilli can convert methionine to dimethyl sulfide, 3(methylsulfanyl) propan-1-ol, methanethiol, and 3-(methylsulfanyl)-propanoic acid; whereas O. oeni strains can use cysteine to produce thiazoles, thus resulting in aroma descriptors such as "sulfury," "roasted," or "toasted" [122]. Investigations have recently examined the potential enzymes in depth, and codified the genes for the catabolic pathway of methionine in LAB during the MLF process $[122,123]$

\subsection{Production of By-products Harmful to Consumer Health (i.e., BAs, EC)}

Even though LAB are considered fundamental to the completion of wine fermentation, they also can represent a cause of alarm for human health, since they can synthesise harmful compounds such as BAs and ethyl carbamate (EC) [124,125].

Histamine, putrescine, and tyramine are the BAs most frequently detected in contaminated wine. They are formed after enzymatic decarboxylation of their respective amino acid precursors, histidine, ornithine, and tyramine [126]. Tyramine and histamine are the 
most harmful to human health. The concomitant presence of other BAs, such as putrescine and cadaverine, can enhance this dangerous action [127]. LAB's role in biogenic amines' biosynthesis has been widely reported [125], with relevant cases also in the oenological field (Table 3).

Table 3. A nonexhaustive list of biogenic amine (BAs)-producing LAB species in wine.

\begin{tabular}{ccc}
\hline Microbial Species & Produced BAs & References \\
\hline Enterococcus faecium & tyramine & {$[128]$} \\
Levilactobacillus brevis & tyramine, putrescine, phenylethylamine & {$[129-132]$} \\
Lentilactobacillus hilgardii & histamine, tyramine, putrescine, phenylethylamine & {$[130,131,133,134]$} \\
Lactiplantibacillus plantarum & tyramine & {$[135]$} \\
Lacticaseibacillus rhamnosus & histamine & {$[136]$} \\
Oenococcus oeni & histamine, putrescine & {$[137,138]$} \\
Pediococcus parvulus & histamine & {$[139]$} \\
\hline
\end{tabular}

Note: BAs, biogenic amines.

The ability to synthesise BAs is likely to be strain-dependent and not a species-specific property, and it is enhanced by favourable conditions for bacterial growth (availability of nutrients) and decarboxylating activity (low pH of wine) [140,141]. Several studies have documented $O$. oeni strains' contribution to the histamine content in wines and the presence of putrescine and cadaverine contaminated grape musts $[142,143]$. Strains of the genus Pediococcus can also be responsible for producing BAs in wines [144]. Concerning lactobacilli, strains belonging to different species demonstrated the ability to synthesise histamine and tyramine $[138,145]$. The lack of BAs production should thus be considered a pivotal parameter for the oenological selection of $\mathrm{LAB}$, as demonstrated by recent investigations regarding the identification of autochthonous bacterial strains unable to form BAs during MLF [74,146]. Microorganisms capable of amino acid decarboxylation can be identified by applying a plate test with specific growth media [147], as well as specific molecular PCR-based approaches, including multiplex amplification or sensitive on-chip approaches [148]. To control BAs contamination in wine, the microbial management of MLF has been proposed by adopting starter cultures unable to produce BAs and able to dominate the indigenous microbiota that constitute the wine ecological niche [74,144]. No technological approaches are available to lower the amount of BAs in contaminated wine.

Ethyl carbamate (EC) is a carcinogenic molecule produced throughout the fermentation process by a non-enzymatic reaction between ethanol and a compound containing a carbamyl group. The principal carbamyl group implicated in EC synthesis is urea derived by the yeast metabolism of arginine, citrulline, and carbamyl phosphate [149]. Arginine deiminase promotes, by arginine deamination, the formation of citrulline, one of the main precursors for EC formation [124]. Heterofermentative LAB, such as L. hilgardii, L. plantarum, L. buchneri, and O. oeni, can actively catabolise arginine [150-152]. Several abiotic factors can enhance ethyl carbamate production, i.e., needless nitrogen adding in the vineyard, low wine $\mathrm{pH}$, high storage temperature, elevated ethanol concentrations and relevant malic acid concentrations [31]. Moreover, EC's presence can be lowered by impairing the synthesis of its precursors, and this goal can be achieved through the employment of a LAB starter culture that produces low concentrations of citrulline [124].

\section{Novel Inoculation Approaches to Enhance LAB Impact on Wine Quality}

The simultaneous inoculation of selected strains of LAB species together with starter yeast directly into the must at the beginning of the alcoholic fermentation is considered a promising practice for improving the quality and safety of wine production $[153,154]$. This approach allows the simultaneous promotion of alcoholic fermentations (AF) and malolactic (MLF) fermentations [155] to avoid possible MLF arrests, generally caused by high ethanol concentrations, high acidity, and nutrient scarcity that characterize the wine at the end of AF [156]. Moreover, LAB and yeast co-inoculation demonstrated an 
ability to reduce production time, improving the quality and the safety of the produced wine [156]. However, despite the above advantages, the yeast/lactic bacteria co-inoculation approach can be applied, subject to the preliminary study of the mutual influence and coexistence capacity between specific strains of $S$. cerevisiae and lactic acid bacteria when inoculated together [157]. Specific compatibilities have been observed between commercial yeasts and LAB strains, suggesting the importance of estimating different starters microbial compatibility before their use in large-scale winemaking [157]. Recent studies have been conducted that investigated the interactions between yeast and commercial LAB strains after their inoculation into must [13]. All the evidence indicated that the two starters' simultaneous inoculation allowed for the rapid development of bacterial populations, resulting in a drastic reduction in the time required for MLF to take place and in the volatile acidity values in the wine produced. Another important advantage of the simultaneous yeast/bacteria inoculation is the reduction of the content of biogenic amines in wines produced in this way, compared to those obtained with the bacterium inoculation at the end of AF $[158,159]$. The co-inoculation approach was recently presented using selected strains of Latiplantibacillus plantarum as a malolactic starter [25]. Co-inoculation of S. cerevisiae and L. plantarum in grape must implemented the levels of adaptation of the bacterium to the harsh conditions of the wine, again reducing the time required for completion of MLF $[18,32,160]$. Increasing interest has been directed toward understanding the interactions between S. cerevisiae and non-Saccharomyces strains with different LAB species [161,162]. The species-specific impact in wineries has been recently assessed by studies that carried out vinification tests at the industrial scale $[8,163]$. The obtained results highlighted the impact of the different combinations of the strains on the "volatome" of produced wine, with specific attention paid to the effects of the concurrent inoculation of the LAB species, thus confirming that the aromatic complexity of the wine reflected the formulation of the starter cultures [164]. Increasing interest has been directed toward the use of immobilised cells for the production of fermented beverages. This strategy offers numerous technical and economic advantages and it can positively influence bacterial metabolism, affecting wine quality and aroma [165]. Immobilisation systems also benefit from recycling the biocatalysts numerous times, thus maintaining the fermentation activity [166]. Starter strains of O. oeni have also been immobilised with good results [167]. Malolactic starters included in plant waste (cobs, grape skins, and stems) have been used to promote MLF in white wine, showing a positive protective effect of immobilisation against stress caused by ethanol concentration and the presence of $\mathrm{SO}_{2}$ on bacterial cells [168]. S. cerevisiae and LAB cells can be included on residues of vegetable origin or in calcium alginate spheres allowed the promotion of FA and MLF simultaneously. Recently, Bleve et al. [169] produced the co-immobilisation of S. cerevisiae and O. oeni cells in alginate drops, and they have used them in microvinifications. This mixed starter allowed for efficient AF and MLF fermentation processes, producing wines enhanced in their organoleptic properties compared with wines produced by the traditional sequential inoculation free cell starters.

\section{Conclusions}

The achievement of MLF depends on either the viability or metabolic performances of the LAB starter culture and the management of several physicochemical parameters of the fermentation process. MLF represents a fundamental step in winemaking that ensures microbial stability, reduced total acidity, and enhancement of aroma and flavour profiles in wines [5,59]. The continuous characterisation of the biodiversity associated with spontaneous fermentation will have, in the near future, a fundamental importance in selecting new starter cultures, designing tailored microbial resources for traditional/typical wines, and conceiving sustainable innovations in winemaking, including biotechnological solutions to the negative impact of climate change $[18,27,62,101,170]$. This up-to-date literature review summarises both the positive and negative influences of malolactic bacteria on wine 
quality and safety, underlining species- and strain-dependent characteristics, and looking toward a more competitive and resilient wine industry.

Author Contributions: Investigation, V.C., M.T., M.F., N.D.S. and F.G.; conceptualization, V.C., M.T., M.F. and F.G.; literature search, V.C., M.T., M.F., N.D.S. and F.G.; writing-original draft preparation, M.T. and F.G.; writing-review and editing, V.C., N.D.S. and M.F. All authors have read and agreed to the published version of the manuscript.

Funding: This research was partially founded by the APULIA REGION, with the projects: "Innovazione nella tradizione: tecnologie innovative per esaltare le qualità dei vini autoctoni spumante della murgia barese-INVISPUBA" (P.S.R. Puglia 2014/2020 -Misura 16.2); and "Birra: dal campo al boccale-BE^2R" (P.S.R. Puglia 2014/2020 -Misura 16.2).

Acknowledgments: We would like to thank Domenico Genchi and Giovanni Colella of the Institute of Sciences of Food Production-CNR for their skilled technical support provided during the realisation of this work.

Conflicts of Interest: The authors declare no conflict of interest.

\section{References}

1. Virdis, C.; Sumby, K.; Bartowsky, E.; Jiranek, V. Lactic Acid Bacteria in Wine: Technological Advances and Evaluation of Their Functional Role. Front. Microbiol. 2020, 11. [CrossRef]

2. Lonvaud-Funel, A. Lactic Acid Bacteria in the Quality Improvement and Depreciation of Wine. Antonie Van Leeuwenhoek 1999, 76, 317-331. [CrossRef] [PubMed]

3. Tufariello, M.; Chiriatti, M.A.; Grieco, F.; Perrotta, C.; Capone, S.; Rampino, P.; Tristezza, M.; Mita, G.; Grieco, F. Influence of Autochthonous Saccharomyces cerevisiae Strains on Volatile Profile of Negroamaro Wines. LWT Food Sci. Technol. 2014, 58 , 35-48. [CrossRef]

4. Berbegal, C.; Khomenko, I.; Russo, P.; Spano, G.; Fragasso, M.; Biasioli, F.; Capozzi, V. PTR-ToF-MS for the Online Monitoring of Alcoholic Fermentation in Wine: Assessment of VOCs Variability Associated with Different Combinations of Saccharomyces/NonSaccharomyces as a Case-Study. Fermentation 2020, 6, 55. [CrossRef]

5. Bartowsky, E.J. Wines. Malolactic Fermentation. In Encyclopedia of Food Microbiology, 2nd ed.; Batt, C.A., Tortorello, M.L., Eds.; Academic Press: Oxford, UK, 2014; pp. 800-804. ISBN 978-0-12-384733-1.

6. Garofalo, C.; Arena, M.P.; Laddomada, B.; Cappello, M.S.; Bleve, G.; Grieco, F.; Beneduce, L.; Berbegal, C.; Spano, G.; Capozzi, V. Starter Cultures for Sparkling Wine. Fermentation 2016, 2, 21. [CrossRef]

7. Lombardi, S.J.; Pannella, G.; Iorizzo, M.; Testa, B.; Succi, M.; Tremonte, P.; Sorrentino, E.; Di Renzo, M.; Strollo, D.; Coppola, R. Inoculum Strategies and Performances of Malolactic Starter Lactobacillus plantarum M10: Impact on Chemical and Sensorial Characteristics of Fiano Wine. Microorganisms 2020, 8, 516. [CrossRef]

8. Tufariello, M.; Capozzi, V.; Spano, G.; Cantele, G.; Venerito, P.; Mita, G.; Grieco, F. Effect of Co-Inoculation of Candida zemplinina, Saccharomyces cerevisiae and Lactobacillus plantarum for the Industrial Production of Negroamaro Wine in Apulia (Southern Italy). Microorganisms 2020, 8, 726. [CrossRef]

9. Lasik-Kurdyś, M.; Majcher, M.; Nowak, J. Effects of Different Techniques of Malolactic Fermentation Induction on Diacetyl Metabolism and Biosynthesis of Selected Aromatic Esters in Cool-Climate Grape Wines. Molecules 2018, 23, 2549. [CrossRef]

10. Iorizzo, M.; Testa, B.; Lombardi, S.J.; García-Ruiz, A.; Muñoz-González, C.; Bartolomé, B.; Moreno-Arribas, M.V. Selection and Technological Potential of Lactobacillus plantarum Bacteria Suitable for Wine Malolactic Fermentation and Grape Aroma Release. LWT 2016, 73, 557-566. [CrossRef]

11. Takase, H.; Sasaki, K.; Kiyomichi, D.; Kobayashi, H.; Matsuo, H.; Takata, R. Impact of Lactobacillus plantarum on Thiol Precursor Biotransformation Leading to Production of 3-Sulfanylhexan-1-Ol. Food Chem. 2018, 259, 99-104. [CrossRef]

12. Lytra, G.; Miot-Sertier, C.; Moine, V.; Coulon, J.; Barbe, J.-C. Influence of Must Yeast-Assimilable Nitrogen Content on Fruity Aroma Variation during Malolactic Fermentation in Red Wine. Food Res. Int. 2020, 135, 109294. [CrossRef] [PubMed]

13. Tristezza, M.; Tufariello, M.; Capozzi, V.; Spano, G.; Mita, G.; Grieco, F. The Oenological Potential of Hanseniaspora uvarum in Simultaneous and Sequential Co-Fermentation with Saccharomyces cerevisiae for Industrial Wine Production. Front. Microbiol. 2016, 7, 670. [CrossRef] [PubMed]

14. Berbegal, C.; Borruso, L.; Fragasso, M.; Tufariello, M.; Russo, P.; Brusetti, L.; Spano, G.; Capozzi, V. A Metagenomic-Based Approach for the Characterization of Bacterial Diversity Associated with Spontaneous Malolactic Fermentations in Wine. Int. J. Mol. Sci. 2019, 20, 3980. [CrossRef]

15. Kioroglou, D.; LLeixá, J.; Mas, A.; Portillo, M.D.C. Massive Sequencing: A New Tool for the Control of Alcoholic Fermentation in Wine? Fermentation 2018, 4, 7. [CrossRef]

16. Abdo, H.; Catacchio, C.R.; Ventura, M.; D'Addabbo, P.; Alexandre, H.; Guilloux-Bénatier, M.; Rousseaux, S. The Establishment of a Fungal Consortium in a New Winery. Sci. Rep. 2020, 10. [CrossRef] 
17. Sumby, K.M.; Grbin, P.R.; Jiranek, V. Implications of New Research and Technologies for Malolactic Fermentation in Wine. Appl. Microbiol. Biotechnol. 2014, 98, 8111-8132. [CrossRef] [PubMed]

18. Lerm, E.; Engelbrecht, L.; du Toit, M. Selection and Characterisation of Oenococcus oeni and Lactobacillus plantarum South African Wine Isolates for Use as Malolactic Fermentation Starter Cultures. South Afr. J. Enol. Vitic. 2011, 32, 280-295. [CrossRef]

19. Dicks, L.M.T.; Endo, A. Taxonomic Status of Lactic Acid Bacteria in Wine and Key Characteristics to Differentiate Species. South Afr. J. Enol. Vitic. 2009, 30, 72-90. [CrossRef]

20. Mesas, J.M.; Rodríguez, M.C.; Alegre, M.T. Characterization of Lactic Acid Bacteria from Musts and Wines of Three Consecutive Vintages of Ribeira Sacra. Lett. Appl. Microbiol. 2011, 52, 258-268. [CrossRef]

21. Rodas, A.M.; Ferrer, S.; Pardo, I. Polyphasic Study of Wine Lactobacillus Strains: Taxonomic Implications. Int. J. Syst. Evol. Microbiol. 2005, 55, 197-207. [CrossRef]

22. König, H.; Fröhlich, J. Lactic Acid Bacteria. In Biology of Microorganisms on Grapes, in Must and in Wine; König, H., Unden, G., Fröhlich, J., Eds.; Springer: Cham, Switzerland, 2017; pp. 3-41. ISBN 978-3-319-60021-5.

23. Franquès, J.; Araque, I.; Palahí, E.; Portillo, M.d.C.; Reguant, C.; Bordons, A. Presence of Oenococcus oeni and Other Lactic Acid Bacteria in Grapes and Wines from Priorat (Catalonia, Spain). LWT Food Sci. Technol. 2017, 81, 326-334. [CrossRef]

24. Miranda-Castilleja, D.E.; Martínez-Peniche, R.Á.; Aldrete-Tapia, J.A.; Soto-Muñoz, L.; Iturriaga, M.H.; Pacheco-Aguilar, J.R.; Arvizu-Medrano, S.M. Distribution of Native Lactic Acid Bacteria in Wineries of Queretaro, Mexico and Their Resistance to Wine-Like Conditions. Front. Microbiol. 2016, 7. [CrossRef] [PubMed]

25. Krieger-Weber, S.; Heras, J.M.; Suarez, C. Lactobacillus Plantarum, a New Biological Tool to Control Malolactic Fermentation: A Review and an Outlook. Beverages 2020, 6, 23. [CrossRef]

26. Lorentzen, M.P.G.; Lucas, P.M. Distribution of Oenococcus oeni Populations in Natural Habitats. Appl. Microbiol. Biotechnol. 2019, 103, 2937-2945. [CrossRef]

27. Capozzi, V.; Russo, P.; Beneduce, L.; Weidmann, S.; Grieco, F.; Guzzo, J.; Spano, G. Technological Properties of Oenococcus oeni Strains Isolated from Typical Southern Italian Wines. Lett. Appl. Microbiol. 2010, 50, 327-334. [CrossRef]

28. Guzzo, J. Stress Responses of Oenococcus oeni. In Stress Responses of Lactic Acid Bacteria; Tsakalidou, E., Papadimitriou, K., Eds.; Springer: Boston, MA, USA, 2011; pp. 349-365. ISBN 978-0-387-92771-8.

29. Acevedo, W.; Cañón, P.; Gómez-Alvear, F.; Huerta, J.; Aguayo, D.; Agosin, E. L-Malate (-2) Protonation State Is Required for Efficient Decarboxylation to l-Lactate by the Malolactic Enzyme of Oenococcus oeni. Molecules 2020, 25, 3431. [CrossRef]

30. Zheng, J.; Wittouck, S.; Salvetti, E.; Franz, C.M.A.P.; Harris, H.M.B.; Mattarelli, P.; O’Toole, P.W.; Pot, B.; Vandamme, P.; Walter, J.; et al. A Taxonomic Note on the Genus Lactobacillus: Description of 23 Novel Genera, Emended Description of the Genus Lactobacillus Beijerinck 1901, and Union of Lactobacillaceae and Leuconostocaceae. Int. J. Syst. Evol. Microbiol. 2020, 70, $2782-2858$. [CrossRef]

31. Du Toit, M.; Engelbrecht, L.; Lerm, E.; Krieger-Weber, S. Lactobacillus: The Next Generation of Malolactic Fermentation Starter Cultures-An Overview. Food Bioprocess Technol. 2011, 4, 876-906. [CrossRef]

32. Berbegal, C.; Peña, N.; Russo, P.; Grieco, F.; Pardo, I.; Ferrer, S.; Spano, G.; Capozzi, V. Technological Properties of Lactobacillus plantarum Strains Isolated from Grape Must Fermentation. Food Microbiol. 2016, 57, 187-194. [CrossRef]

33. Mtshali, P.S.; Divol, B.; Van Rensburg, P.; Du Toit, M. Genetic Screening of Wine-Related Enzymes in Lactobacillus Species Isolated from South African Wines. J. Appl. Microbiol. 2010, 108, 1389-1397. [CrossRef]

34. Sereni, A.; Phan, Q.; Osborne, J.; Tomasino, E. Impact of the Timing and Temperature of Malolactic Fermentation on the Aroma Composition and Mouthfeel Properties of Chardonnay Wine. Foods 2020, 9, 802. [CrossRef] [PubMed]

35. González-Centeno, M.R.; Chira, K.; Teissedre, P.-L. Comparison between Malolactic Fermentation Container and Barrel Toasting Effects on Phenolic, Volatile, and Sensory Profiles of Red Wines. J. Agric. Food Chem. 2017, 65, 3320-3329. [CrossRef]

36. Wade, M.E.; Strickland, M.T.; Osborne, J.P.; Edwards, C.G. Role of Pediococcus in Winemaking. Aust. J. Grape Wine Res. 2019, 25, 7-24. [CrossRef]

37. Juega, M.; Costantini, A.; Bonello, F.; Cravero, M.-C.; Martinez-Rodriguez, A.J.; Carrascosa, A.V.; Garcia-Moruno, E. Effect of Malolactic Fermentation by Pediococcus damnosus on the Composition and Sensory Profile of Albariño and Caiño White Wines. J. Appl. Microbiol. 2014, 116, 586-595. [CrossRef]

38. Mills, D.A.; Rawsthorne, H.; Parker, C.; Tamir, D.; Makarova, K. Genomic Analysis of Oenococcus oeni PSU-1 and Its Relevance to Winemaking. FEMS Microbiol. Rev. 2005, 29, 465-475. [CrossRef]

39. Borneman, A.R.; McCarthy, J.M.; Chambers, P.J.; Bartowsky, E.J. Comparative Analysis of the Oenococcus oeni Pan Genome Reveals Genetic Diversity in Industrially-Relevant Pathways. BMC Genom. 2012, 13, 373. [CrossRef] [PubMed]

40. Lamontanara, A.; Orrù, L.; Cattivelli, L.; Russo, P.; Spano, G.; Capozzi, V. Genome Sequence of Oenococcus oeni OM27, the First Fully Assembled Genome of a Strain Isolated from an Italian Wine. Genome Announc. 2014, 2. [CrossRef] [PubMed]

41. Capozzi, V.; Russo, P.; Lamontanara, A.; Orrù, L.; Cattivelli, L.; Spano, G. Genome Sequences of Five Oenococcus oeni Strains Isolated from Nero Di Troia Wine from the Same Terroir in Apulia, Southern Italy. Genome Announc. 2014, 2. [CrossRef]

42. Campbell-Sills, H.; Khoury, M.E.; Gammacurta, M.; Miot-Sertier, C.; Dutilh, L.; Vestner, J.; Capozzi, V.; Sherman, D.; Hubert, C.; Claisse, O.; et al. Two Different Oenococcus oeni Lineages Are Associated to Either Red or White Wines in Burgundy: Genomics and Metabolomics Insights. OENO One 2017, 51, 309. [CrossRef] 
43. Campbell-Sills, H.; El Khoury, M.; Favier, M.; Romano, A.; Biasioli, F.; Spano, G.; Sherman, D.J.; Bouchez, O.; Coton, E.; Coton, M.; et al. Phylogenomic Analysis of Oenococcus oeni Reveals Specific Domestication of Strains to Cider and Wines. Genome Biol. Evol. 2015, 7, 1506-1518. [CrossRef]

44. Mendoza, L.M.; Saavedra, L.; Raya, R.R. Draft Genome Sequence of Oenococcus oeni Strain X2L (CRL1947), Isolated from Red Wine of Northwest Argentina. Genome Announc. 2015, 3. [CrossRef] [PubMed]

45. Sternes, P.R.; Borneman, A.R. Consensus Pan-Genome Assembly of the Specialised Wine Bacterium Oenococcus oeni. BMC Genom. 2016, 17, 308. [CrossRef]

46. Iglesias, N.G.; Valdés La Hens, D.; Olguin, N.T.; Bravo-Ferrada, B.M.; Brizuela, N.S.; Tymczyszyn, E.E.; Bibiloni, H.; Caballero, A.C.; Delfederico, L.; Semorile, L. Genome Sequence of Oenococcus oeni UNQOe19, the First Fully Assembled Genome Sequence of a Patagonian Psychrotrophic Oenological Strain. Microbiol. Resour. Announc. 2018, 7. [CrossRef] [PubMed]

47. Lamontanara, A.; Caggianiello, G.; Orrù, L.; Capozzi, V.; Michelotti, V.; Bayjanov, J.R.; Renckens, B.; van Hijum, S.A.F.T.; Cattivelli, L.; Spano, G. Draft Genome Sequence of Lactobacillus plantarum Lp90 Isolated from Wine. Genome Announc. 2015, 3. [CrossRef]

48. Zhao, M.; Liu, S.; He, L.; Tian, Y. Draft Genome Sequence of Lactobacillus plantarum XJ25 Isolated from Chinese Red Wine. Genome Announc. 2016, 4. [CrossRef]

49. Iglesias, N.G.; Brizuela, N.S.; Tymczyszyn, E.E.; Hollmann, A.; Hens, D.V.L.; Semorile, L.; Bravo-Ferrada, B.M. Complete Genome Sequencing of Lactobacillus plantarum UNQLp 11 Isolated from a Patagonian Pinot Noir Wine. South Afr. J. Enol. Vitic. 2020, 41, 197-209. [CrossRef]

50. Betteridge, A.; Grbin, P.; Jiranek, V. Improving Oenococcus oeni to Overcome Challenges of Wine Malolactic Fermentation. Trends Biotechnol. 2015, 33, 547-553. [CrossRef]

51. Quirós, C.; Herrero, M.; García, L.A.; Díaz, M. Effects of SO2 on Lactic Acid Bacteria Physiology When Used as a Preservative Compound in Malolactic Fermentation. J. Inst. Brew. 2012, 118, 89-96. [CrossRef]

52. Knoll, C.; Fritsch, S.; Schnell, S.; Grossmann, M.; Rauhut, D.; du Toit, M. Influence of pH and Ethanol on Malolactic Fermentation and Volatile Aroma Compound Composition in White Wines. LWT Food Sci. Technol. 2011, 44, 2077-2086. [CrossRef]

53. Zhao, H.; Liu, L.; Yuan, L.; Hu, K.; Peng, S.; Li, H.; Wang, H. Mechanism Analysis of Combined Acid-and-Ethanol Shock on Oenococcus oeni Using RNA-Seq. Eur. Food Res. Technol. 2020, 246, 1637-1646. [CrossRef]

54. Contreras, A.; Ribbeck, M.; Gutiérrez, G.D.; Cañon, P.M.; Mendoza, S.N.; Agosin, E. Mapping the Physiological Response of Oenococcus oeni to Ethanol Stress Using an Extended Genome-Scale Metabolic Model. Front. Microbiol. 2018, 9. [CrossRef] [PubMed]

55. Guan, N.; Liu, L. Microbial Response to Acid Stress: Mechanisms and Applications. Appl. Microbiol. Biotechnol. 2020, 104, 51-65. [CrossRef] [PubMed]

56. Bauer, R.; Dicks, L.M.T. Control of Malolactic Fermentation in Wine. A Review. South Afr. J. Enol. Vitic. 2004, 25, 74-88. [CrossRef]

57. Herrero, M.; García, L.A.; Díaz, M. Volatile Compounds in Cider: Inoculation Time and Fermentation Temperature Effects. J. Inst. Brew. 2006, 112, 210-214. [CrossRef]

58. Guzzon, R.; Roman, T.; Larcher, R. Impact of Different Temperature Profiles on Simultaneous Yeast and Bacteria Fermentation. Ann. Microbiol. 2020, 70, 44. [CrossRef]

59. Bartowsky, E.J.; Costello, P.J.; Chambers, P.J. Emerging Trends in the Application of Malolactic Fermentation. Aust. J. Grape Wine Res. 2015, 21, 663-669. [CrossRef]

60. Belda, I.; Ruiz, J.; Esteban-Fernández, A.; Navascués, E.; Marquina, D.; Santos, A.; Moreno-Arribas, M.V. Microbial Contribution to Wine Aroma and Its Intended Use for Wine Quality Improvement. Molecules 2017, 22, 189. [CrossRef]

61. Cappello, M.S.; Zapparoli, G.; Logrieco, A.; Bartowsky, E.J. Linking Wine Lactic Acid Bacteria Diversity with Wine Aroma and Flavour. Int. J. Food Microbiol. 2017, 243, 16-27. [CrossRef]

62. Berbegal, C.; Fragasso, M.; Russo, P.; Bimbo, F.; Grieco, F.; Spano, G.; Capozzi, V. Climate Changes and Food Quality: The Potential of Microbial Activities as Mitigating Strategies in the Wine Sector. Fermentation 2019, 5, 85. [CrossRef]

63. Antalick, G.; Perello, M.-C.; De Revel, G. Characterization of Fruity Aroma Modifications in Red Wines during Malolactic Fermentation. J. Agric. Food Chem. 2012, 60, 12371-12383. [CrossRef]

64. Sumby, K.M.; Jiranek, V.; Grbin, P.R. Ester Synthesis and Hydrolysis in an Aqueous Environment, and Strain Specific Changes during Malolactic Fermentation in Wine with Oenococcus oeni. Food Chem. 2013, 141, 1673-1680. [CrossRef] [PubMed]

65. Gammacurta, M.; Lytra, G.; Marchal, A.; Marchand, S.; Christophe Barbe, J.; Moine, V.; de Revel, G. Influence of Lactic Acid Bacteria Strains on Ester Concentrations in Red Wines: Specific Impact on Branched Hydroxylated Compounds. Food Chem. 2018, 239, 252-259. [CrossRef]

66. Sumby, K.M.; Grbin, P.R.; Jiranek, V. Characterization of EstCOo8 and EstC34, Intracellular Esterases, from the Wine-Associated Lactic Acid Bacteria Oenococcus oeni and Lactobacillus hilgardii. J. Appl. Microbiol. 2013, 114, 413-422. [CrossRef] [PubMed]

67. Lerm, E.; Engelbrecht, L.; Du Toit, M. Malolactic Fermentation: The ABC's of MLF. S. Afr. J. Enol. Vitic. 2010, 31, 186-212. [CrossRef]

68. Pérez-Martín, F.; Seseña, S.; Izquierdo, P.M.; Palop, M.L. Esterase Activity of Lactic Acid Bacteria Isolated from Malolactic Fermentation of Red Wines. Int. J. Food Microbiol. 2013, 163, 153-158. [CrossRef] [PubMed]

69. Costello, P.J.; Siebert, T.E.; Solomon, M.R.; Bartowsky, E.J. Synthesis of Fruity Ethyl Esters by Acyl Coenzyme A: Alcohol Acyltransferase and Reverse Esterase Activities in Oenococcus oeni and Lactobacillus plantarum. J. Appl. Microbiol. 2013, 114, 797-806. [CrossRef] 
70. Esteban-Torres, M.; Reverón, I.; Mancheño, J.M.; de las Rivas, B.; Muñoz, R. Characterization of a Feruloyl Esterase from Lactobacillus plantarum. Appl. Environ. Microbiol. 2013, 79, 5130-5136. [CrossRef] [PubMed]

71. Osborne, J.P.; Dubé Morneau, A.; Mira de Orduña, R. Degradation of Free and Sulfur-Dioxide-Bound Acetaldehyde by Malolactic Lactic Acid Bacteria in White Wine. J. Appl. Microbiol. 2006, 101, 474-479. [CrossRef]

72. Bartowsky, E.J.; Pretorius, I.S. Microbial Formation and Modification of Flavor and Off-Flavor Compounds in Wine. In Biology of Microorganisms on Grapes, in Must and in Wine; König, H., Unden, G., Fröhlich, J., Eds.; Springer: Cham, Switzerland, 2009; pp. 209-231; ISBN 978-3-540-85463-0.

73. Lasik, M. The Application of Malolactic Fermentation Process to Create Good-Quality Grape Wine Produced in Cool-Climate Countries: A Review. Eur. Food Res. Technol. 2013, 237, 843-850. [CrossRef]

74. Berbegal, C.; Spano, G.; Tristezza, M.; Grieco, F.; Capozzi, V. Microbial Resources and Innovation in the Wine Production Sector. South Afr. J. Enol. Vitic. 2017, 38, 156-166. [CrossRef]

75. Belda, I.; Ruiz, J.; Beisert, B.; Navascués, E.; Marquina, D.; Calderón, F.; Rauhut, D.; Benito, S.; Santos, A. Influence of Torulaspora delbrueckii in Varietal Thiol (3-SH and 4-MSP) Release in Wine Sequential Fermentations. Int. J. Food Microbiol. 2017, 257, 183-191. [CrossRef] [PubMed]

76. Tominaga, T.; Baltenweck-Guyot, R.; Gachons, C.P.D.; Dubourdieu, D. Contribution of Volatile Thiols to the Aromas of White Wines Made from Several Vitis vinifera Grape Varieties. Am. J. Enol. Vitic. 2000, 51, 178-181.

77. Landaud, S.; Helinck, S.; Bonnarme, P. Formation of Volatile Sulfur Compounds and Metabolism of Methionine and Other Sulfur Compounds in Fermented Food. Appl. Microbiol. Biotechnol. 2008, 77, 1191-1205. [CrossRef] [PubMed]

78. Black, C.A.; Parker, M.; Siebert, T.E.; Capone, D.L.; Francis, I.L. Terpenoids and Their Role in Wine Flavour: Recent Advances. Aust. J. Grape Wine Res. 2015, 21, 582-600. [CrossRef]

79. Palmeri, R.; Spagna, G. $\beta$-Glucosidase in Cellular and Acellular Form for Winemaking Application. Enzyme Microb. Technol. 2007, 40, 382-389. [CrossRef]

80. Barbagallo, R.N.; Spagna, G.; Palmeri, R.; Torriani, S. Assessment of $\beta$-Glucosidase Activity in Selected Wild Strains of Oenococcus oeni for Malolactic Fermentation. Enzyme Microb. Technol. 2004, 34, 292-296. [CrossRef]

81. Michlmayr, H.; Kneifel, W. $\beta$-Glucosidase Activities of Lactic Acid Bacteria: Mechanisms, Impact on Fermented Food and Human Health. FEMS Microbiol. Lett. 2014, 352, 1-10. [CrossRef] [PubMed]

82. Michlmayr, H.; Nauer, S.; Brandes, W.; Schümann, C.; Kulbe, K.D.; del Hierro, A.M.; Eder, R. Release of Wine Monoterpenes from Natural Precursors by Glycosidases from Oenococcus oeni. Food Chem. 2012, 135-334, 80-87. [CrossRef]

83. Sestelo, A.B.F.; Poza, M.; Villa, T.G. $\beta$-Glucosidase Activity in a Lactobacillus plantarum Wine Strain. World J. Microbiol. Biotechnol. 2004, 20, 633. [CrossRef]

84. Ugliano, M.; Moio, L. The Influence of Malolactic Fermentation and Oenococcus oeni Strain on Glycosidic Aroma Precursors and Related Volatile Compounds of Red Wine. J. Sci. Food Agric. 2006, 86, 2468-2476. [CrossRef]

85. Russo, P.; Capozzi, V.; Spano, G.; Corbo, M.R.; Sinigaglia, M.; Bevilacqua, A. Metabolites of Microbial Origin with an Impact on Health: Ochratoxin A and Biogenic Amines. Front. Microbiol. 2016, 7, 482. [CrossRef]

86. Tamura, M.; Takahashi, A.; Uyama, A.; Mochizuki, N. A Method for Multiple Mycotoxin Analysis in Wines by Solid Phase Extraction and Multifunctional Cartridge Purification, and Ultra-High-Performance Liquid Chromatography Coupled to Tandem Mass Spectrometry. Toxins 2012, 4, 476-486. [CrossRef]

87. Gil-Serna, J.; Vázquez, C.; González-Jaén, M.T.; Patiño, B. Wine Contamination with Ochratoxins: A Review. Beverages 2018, 4, 6. [CrossRef]

88. Grazioli, B.; Fumi, M.D.; Silva, A. The Role of Processing on Ochratoxin A Content in Italian Must and Wine: A Study on Naturally Contaminated Grapes. Int. J. Food Microbiol. 2006, 111, S93-S96. [CrossRef]

89. Muhialdin, B.J.; Saari, N.; Meor Hussin, A.S. Review on the Biological Detoxification of Mycotoxins Using Lactic Acid Bacteria to Enhance the Sustainability of Foods Supply. Molecules 2020, 25, 2655. [CrossRef]

90. Petruzzi, L.; Bevilacqua, A.; Corbo, M.R.; Speranza, B.; Capozzi, V.; Sinigaglia, M. A Focus on Quality and Safety Traits of Saccharomyces cerevisiae Isolated from Uva di Troia Grape Variety. J. Food Sci. 2017, 82, 124-133. [CrossRef]

91. Del Prete, V.; Rodriguez, H.; Carrascosa, A.V.; de las Rivas, B.; Garcia-Moruno, E.; Muñoz, R. In Vitro Removal of Ochratoxin A by Wine Lactic Acid Bacteria. J. Food Prot. 2007, 70, 2155-2160. [CrossRef] [PubMed]

92. Mateo, E.M.; Medina, Á.; Mateo, F.; Valle-Algarra, F.M.; Pardo, I.; Jiménez, M. Ochratoxin A Removal in Synthetic Media by Living and Heat-Inactivated Cells of Oenococcus oeni Isolated from Wines. Food Control 2010, 21, 23-28. [CrossRef]

93. Abrunhosa, L.; Inês, A.; Rodrigues, A.I.; Guimarães, A.; Pereira, V.L.; Parpot, P.; Mendes-Faia, A.; Venâncio, A. Biodegradation of Ochratoxin A by Pediococcus parvulus Isolated from Douro Wines. Int. J. Food Microbiol. 2014, 188, 45-52. [CrossRef] [PubMed]

94. Beneduce, L.; Romano, A.; Capozzi, V.; Lucas, P.; Barnavon, L.; Bach, B.; Vuchot, P.; Grieco, F.; Spano, G. Biogenic Amine in Wines. Ann. Microbiol. 2010, 60, 573-578. [CrossRef]

95. Silla Santos, M.H. Biogenic Amines: Their Importance in Foods. Int. J. Food Microbiol. 1996, 29, 213-231. [CrossRef]

96. Capozzi, V.; Russo, P.; Ladero, V.; Fernández, M.; Fiocco, D.; Alvarez, M.A.; Grieco, F.; Spano, G. Biogenic Amines Degradation by Lactobacillus plantarum: Toward a Potential Application in Wine. Front. Microbiol. 2012, 3. [CrossRef] [PubMed]

97. Callejón, S.; Sendra, R.; Ferrer, S.; Pardo, I. Identification of a Novel Enzymatic Activity from Lactic Acid Bacteria Able to Degrade Biogenic Amines in Wine. Appl. Microbiol. Biotechnol. 2014, 98, 185-198. [CrossRef] 
98. Niu, T.; Li, X.; Guo, Y.; Ma, Y. Identification of a Lactic Acid Bacteria to Degrade Biogenic Amines in Chinese Rice Wine and Its Enzymatic Mechanism. Foods 2019, 8, 312. [CrossRef]

99. Sun, S.; Jiang, D.; Fan, M.; Li, H.; Jin, C.; Liu, W. Selection of a Versatile Lactobacillus plantarum for Wine Production and Identification and Preliminary Characterisation of a Novel Histamine-Degrading Enzyme. Int. J. Food Sci. Technol. 2020, 55, 2608-2618. [CrossRef]

100. Agriopoulou, S.; Stamatelopoulou, E.; Sachadyn-Król, M.; Varzakas, T. Lactic Acid Bacteria as Antibacterial Agents to Extend the Shelf Life of Fresh and Minimally Processed Fruits and Vegetables: Quality and Safety Aspects. Microorganisms 2020, 8, 952. [CrossRef]

101. Nardi, T. Microbial Resources as a Tool for Enhancing Sustainability in Winemaking. Microorganisms 2020, 8, 507. [CrossRef]

102. Russo, P.; Berbegal, C.; De Ceglie, C.; Grieco, F.; Spano, G.; Capozzi, V. Pesticide Residues and Stuck Fermentation in Wine: New Evidences Indicate the Urgent Need of Tailored Regulations. Fermentation 2019, 5, 23. [CrossRef]

103. De Simone, N.; Pace, B.; Grieco, F.; Chimienti, M.; Tyibilika, V.; Santoro, V.; Capozzi, V.; Colelli, G.; Spano, G.; Russo, P. Botrytis cinerea and Table Grapes: A Review of the Main Physical, Chemical, and Bio-Based Control Treatments in Post-Harvest. Foods 2020, 9, 1138. [CrossRef] [PubMed]

104. Russo, P.; Fares, C.; Longo, A.; Spano, G.; Capozzi, V. Lactobacillus plantarum with Broad Antifungal Activity as a Protective Starter Culture for Bread Production. Foods 2017, 6, 110. [CrossRef]

105. Voidarou, C.; Alexopoulos, A.; Tsinas, A.; Rozos, G.; Tzora, A.; Skoufos, I.; Varzakas, T.; Bezirtzoglou, E. Effectiveness of Bacteriocin-Producing Lactic Acid Bacteria and Bifidobacterium Isolated from Honeycombs against Spoilage Microorganisms and Pathogens Isolated from Fruits and Vegetables. Appl. Sci. 2020, 10, 7309. [CrossRef]

106. Mokoena, M.P. Lactic Acid Bacteria and Their Bacteriocins: Classification, Biosynthesis and Applications against Uropathogens: A Mini-Review. Molecules 2017, 22, 1255. [CrossRef]

107. Arena, M.P.; Capozzi, V.; Russo, P.; Drider, D.; Spano, G.; Fiocco, D. Immunobiosis and Probiosis: Antimicrobial Activity of Lactic Acid Bacteria with a Focus on Their Antiviral and Antifungal Properties. Appl. Microbiol. Biotechnol. 2018, 102, 9949-9958. [CrossRef]

108. Arena, M.P.; Russo, P.; Spano, G.; Capozzi, V. Exploration of the Microbial Biodiversity Associated with North Apulian Sourdoughs and the Effect of the Increasing Number of Inoculated Lactic Acid Bacteria Strains on the Biocontrol against Fungal Spoilage. Fermentation 2019, 5, 97. [CrossRef]

109. Dean, R.; Van Kan, J.A.L.; Pretorius, Z.A.; Hammond-Kosack, K.E.; Pietro, A.D.; Spanu, P.D.; Rudd, J.J.; Dickman, M.; Kahmann, R.; Ellis, J.; et al. The Top 10 Fungal Pathogens in Molecular Plant Pathology. Mol. Plant Pathol. 2012, 13, 414-430. [CrossRef] [PubMed]

110. De Senna, A.; Lathrop, A. Antifungal Screening of Bioprotective Isolates against Botrytis cinerea, Fusarium pallidoroseum and Fusarium moniliforme. Fermentation 2017, 3, 53. [CrossRef]

111. Trias, R.; Bañeras, L.; Badosa, E.; Montesinos, E. Bioprotection of Golden Delicious Apples and Iceberg Lettuce against Foodborne Bacterial Pathogens by Lactic Acid Bacteria. Int. J. Food Microbiol. 2008, 123, 50-60. [CrossRef] [PubMed]

112. López-Seijas, J.; García-Fraga, B.; da Silva, A.F.; Sieiro, C. Wine Lactic Acid Bacteria with Antimicrobial Activity as Potential Biocontrol Agents against Fusarium oxysporum f. sp. lycopersici. Agronomy 2020, 10, 31. [CrossRef]

113. Berbegal, C.; Spano, G.; Fragasso, M.; Grieco, F.; Russo, P.; Capozzi, V. Starter Cultures as Biocontrol Strategy to Prevent Brettanomyces bruxellensis Proliferation in Wine. Appl. Microbiol. Biotechnol. 2018, 102, 569-576. [CrossRef]

114. Di Toro, M.R.; Capozzi, V.; Beneduce, L.; Alexandre, H.; Tristezza, M.; Durante, M.; Tufariello, M.; Grieco, F.; Spano, G. Intraspecific Biodiversity and 'Spoilage Potential' of Brettanomyces bruxellensis in Apulian Wines. LWT Food Sci. Technol. 2015, 60, 102-108. [CrossRef]

115. Berbegal, C.; Garofalo, C.; Russo, P.; Pati, S.; Capozzi, V.; Spano, G. Use of Autochthonous Yeasts and Bacteria in Order to Control Brettanomyces bruxellensis in Wine. Fermentation 2017, 3, 65. [CrossRef]

116. Rubio-Bretón, P.; Gonzalo-Diago, A.; Iribarren, M.; Garde-Cerdán, T.; Pérez-Álvarez, E.P. Bioprotection as a Tool to Free Additives Winemaking: Effect on Sensorial, Anthocyanic and Aromatic Profile of Young Red Wines. LWT 2018, 98, 458-464. [CrossRef]

117. Miyagusuku-Cruzado, G.; García-Cano, I.; Rocha-Mendoza, D.; Jiménez-Flores, R.; Giusti, M.M. Monitoring Hydroxycinnamic Acid Decarboxylation by Lactic Acid Bacteria Using High-Throughput UV-Vis Spectroscopy. Molecules 2020, 25, 3142. [CrossRef]

118. Couto, J.A.; Campos, F.M.; Figueiredo, A.R.; Hogg, T.A. Ability of Lactic Acid Bacteria to Produce Volatile Phenols. Am. J. Enol. Vitic. 2006, 57, 166-171.

119. Santamaría, L.; Reverón, I.; de Felipe, F.L.; de Las Rivas, B.; Muñoz, R. Ethylphenol Formation by Lactobacillus plantarum: Identification of the Enzyme Involved in the Reduction of Vinylphenols. Appl. Environ. Microbiol. 2018, 84. [CrossRef]

120. Costello, P.J.; Lee, T.H.; Henschke, P. Ability of Lactic Acid Bacteria to Produce N-Heterocycles Causing Mousy off-Flavour in Wine. Aust. J. Grape Wine Res. 2001, 7, 160-167. [CrossRef]

121. Costello, P.J.; Henschke, P.A. Mousy Off-Flavor of Wine: Precursors and Biosynthesis of the Causative N-Heterocycles 2Ethyltetrahydropyridine, 2-Acetyltetrahydropyridine, and 2-Acetyl-1-Pyrroline by Lactobacillus Hilgardii DSM 20176. J. Agric. Food Chem. 2002, 50, 7079-7087. [CrossRef]

122. Pripis-Nicolau, L.; de Revel, G.; Bertrand, A.; Lonvaud-Funel, A. Methionine Catabolism and Production of Volatile Sulphur Compounds by Oenococcus oeni. J. Appl. Microbiol. 2004, 96, 1176-1184. [CrossRef] [PubMed] 
123. Vallet, A.; Lucas, P.; Lonvaud-Funel, A.; Revel, G.D. Pathways That Produce Volatile Sulphur Compounds from Methionine in Oenococcus oeni. J. Appl. Microbiol. 2008, 104, 1833-1840. [CrossRef]

124. Jiao, Z.; Dong, Y.; Chen, Q. Ethyl Carbamate in Fermented Beverages: Presence, Analytical Chemistry, Formation Mechanism, and Mitigation Proposals. Compr. Rev. Food Sci. Food Saf. 2014, 13, 611-626. [CrossRef]

125. Russo, P.; Fragasso, M.; Berbegal, C.; Grieco, F.; Spano, G.; Capozzi, V. Chapter 2: Microorganisms Able to Produce Biogenic Amines and Factors Affecting Their Activity. In Biogenic Amines in Food; The Royal Society of Chemistry: London, UK, 2019; pp. $18-40$.

126. Barbieri, F.; Montanari, C.; Gardini, F.; Tabanelli, G. Biogenic Amine Production by Lactic Acid Bacteria: A Review. Foods 2019, 8, 17. [CrossRef]

127. Pegg, A.E. Toxicity of Polyamines and Their Metabolic Products. Chem. Res. Toxicol. 2013, 26, 1782-1800. [CrossRef] [PubMed]

128. Capozzi, V.; Ladero, V.; Beneduce, L.; Fernández, M.; Alvarez, M.A.; Benoit, B.; Laurent, B.; Grieco, F.; Spano, G. Isolation and Characterization of Tyramine-Producing Enterococcus faecium Strains from Red Wine. Food Microbiol. 2011, 28, 434-439. [CrossRef]

129. Moreno-Arribas, V.; Lonvaud-Funel, A. Tyrosine Decarboxylase Activity of Lactobacillus brevis IOEB 9809 Isolated from Wine and L. brevis ATCC 367. FEMS Microbiol. Lett. 1999, 180, 55-60. [CrossRef] [PubMed]

130. Moreno-Arribas, V.; Torlois, S.; Joyeux, A.; Bertrand, A.; Lonvaud-Funel, A. Isolation, Properties and Behaviour of TyramineProducing Lactic Acid Bacteria from Wine. J. Appl. Microbiol. 2000, 88, 584-593. [CrossRef] [PubMed]

131. Costantini, A.; Cersosimo, M.; Del Prete, V.; Garcia-Moruno, E. Production of Biogenic Amines by Lactic Acid Bacteria: Screening by PCR, Thin-Layer Chromatography, and High-Performance Liquid Chromatography of Strains Isolated from Wine and Must. J. Food Prot. 2006, 69, 391-396. [CrossRef]

132. Arena, M.P.; Romano, A.; Capozzi, V.; Beneduce, L.; Ghariani, M.; Grieco, F.; Lucas, P.; Spano, G. Expression of Lactobacillus brevis IOEB 9809 Tyrosine Decarboxylase and Agmatine Deiminase Genes in Wine Correlates with Substrate Availability. Lett. Appl. Microbiol. 2011, 53, 395-402. [CrossRef]

133. Mazzoli, R.; Lamberti, C.; Coisson, J.D.; Purrotti, M.; Arlorio, M.; Giuffrida, M.G.; Giunta, C.; Pessione, E. Influence of Ethanol, Malate and Arginine on Histamine Production of Lactobacillus hilgardii Isolated from an Italian Red Wine. Amino Acids 2009, 36, 81-89. [CrossRef]

134. Diez-Ozaeta, I.; Amárita, F.; Lavilla, M.; Rainieri, S. Ecology of Indigenous Lactic Acid Bacteria from Rioja Alavesa Red Wines, Focusing on Biogenic Amine Production Ability. LWT 2019, 116, 108544. [CrossRef]

135. Bonnin-Jusserand, M.; Grandvalet, C.; Rieu, A.; Weidmann, S.; Alexandre, H. Tyrosine-Containing Peptides Are Precursors of Tyramine Produced by Lactobacillus plantarum Strain IR BL0076 Isolated from Wine. BMC Microbiol. 2012, 12, 199. [CrossRef]

136. Henríquez-Aedo, K.; Durán, D.; Garcia, A.; Hengst, M.B.; Aranda, M. Identification of Biogenic Amines-Producing Lactic Acid Bacteria Isolated from Spontaneous Malolactic Fermentation of Chilean Red Wines. LWT Food Sci. Technol. 2016, 68, 183-189. [CrossRef]

137. Marcobal, A.; de Las Rivas, B.; Moreno-Arribas, M.V.; Muñoz, R. Identification of the Ornithine Decarboxylase Gene in the Putrescine-Producer Oenococcus oeni BIFI-83. FEMS Microbiol. Lett. 2004, 239, 213-220. [CrossRef] [PubMed]

138. Lucas, P.M.; Claisse, O.; Lonvaud-Funel, A. High Frequency of Histamine-Producing Bacteria in the Enological Environment and Instability of the Histidine Decarboxylase Production Phenotype. Appl. Environ. Microbiol. 2008, 74, 811-817. [CrossRef] [PubMed]

139. Landete, J.M.; Ferrer, S.; Pardo, I. Which Lactic Acid Bacteria Are Responsible for Histamine Production in Wine? J. Appl. Microbiol. 2005, 99, 580-586. [CrossRef] [PubMed]

140. Costantini, A.; Vaudano, E.; Pulcini, L.; Carafa, T.; Garcia-Moruno, E. An Overview on Biogenic Amines in Wine. Beverages 2019, 5, 19. [CrossRef]

141. Arena, M.P.; Russo, P.; Capozzi, V.; Beneduce, L.; Spano, G. Effect of Abiotic Stress Conditions on Expression of the Lactobacillus brevis IOEB 9809 Tyrosine Decarboxylase and Agmatine Deiminase Genes. Ann. Microbiol. 2011, 61, 179-183. [CrossRef]

142. Garcia-Moruno, E.; Muñoz, R. Does Oenococcus oeni Produce Histamine? Int. J. Food Microbiol. 2012, 157, 121-129. [CrossRef]

143. Izquierdo Cañas, P.M.; Gómez Alonso, S.; Ruiz Pérez, P.; Seseña Prieto, S.; García Romero, E.; Palop Herreros, M.L.L. Biogenic Amine Production by Oenococcus oeni Isolates from Malolactic Fermentation of Tempranillo Wine. J. Food Prot. 2009, 72, 907-910. [CrossRef]

144. Moreno-Arribas, M.V.; Polo, M.C. Occurrence of Lactic Acid Bacteria and Biogenic Amines in Biologically Aged Wines. Food Microbiol. 2008, 25, 875-881. [CrossRef]

145. Sebastian, P.; Herr, P.; Fischer, U.; König, H. Molecular Identification of Lactic Acid Bacteria Occurring in Must and Wine. South Afr. J. Enol. Vitic. 2011, 32, 300-309. [CrossRef]

146. Battistelli, N.; Perpetuini, G.; Perla, C.; Arfelli, G.; Zulli, C.; Rossetti, A.P.; Tofalo, R. Characterization of Natural Oenococcus oeni Strains for Montepulciano d'Abruzzo Organic Wine Production. Eur. Food Res. Technol. 2020, 246, 1031-1039. [CrossRef]

147. Tristezza, M.; Vetrano, C.; Bleve, G.; Spano, G.; Capozzi, V.; Logrieco, A.; Mita, G.; Grieco, F. Biodiversity and Safety Aspects of Yeast Strains Characterized from Vineyards and Spontaneous Fermentations in the Apulia Region, Italy. Food Microbiol. 2013, 36, 335-342. [CrossRef]

148. Sciancalepore, A.G.; Mele, E.; Arcadio, V.; Reddavide, F.; Grieco, F.; Spano, G.; Lucas, P.; Mita, G.; Pisignano, D. MicrodropletBased Multiplex PCR on Chip to Detect Foodborne Bacteria Producing Biogenic Amines. Food Microbiol. 2013, $35,10-14$. [CrossRef] 
149. Vincenzini, M.; Guerrini, S.; Mangani, S.; Granchi, L. Amino Acid Metabolisms and Production of Biogenic Amines and Ethyl Carbamate. In Biology of Microorganisms on Grapes, in Must and in Wine; König, H., Unden, G., Fröhlich, J., Eds.; Springer: Cham, Switzerland, 2017; pp. 231-253. ISBN 978-3-319-60021-5.

150. Uthurry, C.A.; Lepe, J.A.S.; Lombardero, J.; García Del Hierro, J.R. Ethyl Carbamate Production by Selected Yeasts and Lactic Acid Bacteria in Red Wine. Food Chem. 2006, 94, 262-270. [CrossRef]

151. Mira De Orduña, R.; Patchett, M.L.; Liu, S.Q.; Pilone, G.J. Growth and Arginine Metabolism of the Wine Lactic Acid Bacteria Lactobacillus buchneri and Oenococcus oeni at Different $\mathrm{pH}$ Values and Arginine Concentrations. Appl. Environ. Microbiol. 2001, 67, 1657-1662. [CrossRef]

152. Tonon, T.; Lonvaud-Funel, A. Arginine Metabolism by Wine Lactobacilli Isolated from Wine. Food Microbiol. 2002, 19, 451-461. [CrossRef]

153. Cañas, P.M.I.; Pérez-Martín, F.; Romero, E.G.; Prieto, S.S.; de los Llanos Palop Herreros, M. Influence of Inoculation Time of an Autochthonous Selected Malolactic Bacterium on Volatile and Sensory Profile of Tempranillo and Merlot Wines. Int. J. Food Microbiol. 2012, 156, 245-254. [CrossRef]

154. Zapparoli, G.; Tosi, E.; Azzolini, M.; Vagnoli, P.; Krieger, S. Bacterial Inoculation Strategies for the Achievement of Malolactic Fermentation in High-Alcohol Wines. South Afr. J. Enol. Vitic. 2009, 30, 49-55. [CrossRef]

155. Antalick, G.; Perello, M.C.; de Revel, G. Co-Inoculation with Yeast and LAB Under Winery Conditions: Modification of the Aromatic Profile of Merlot Wines. South Afr. J. Enol. Vitic. 2013, 34, 223-232. [CrossRef]

156. Guzzon, R.; Moser, S.; Davide, S.; Villegas, T.R.; Malacarne, M.; Larcher, R.; Nardi, T.; Vagnoli, P.; Krieger-Weber, S. Exploitation of Simultaneous Alcoholic and Malolactic Fermentation of Incrocio Manzoni, a Traditional Italian White Wine. South Afr. J. Enol. Vitic. 2016, 37, 124-131. [CrossRef]

157. Bartle, L.; Sumby, K.; Sundstrom, J.; Jiranek, V. The Microbial Challenge of Winemaking: Yeast-Bacteria Compatibility. FEMS Yeast Res. 2019, 19. [CrossRef]

158. Rodríguez-Nogales, J.M.; Simó, G.; Pérez-Magariño, S.; Cano-Mozo, E.; Fernández-Fernández, E.; Ruipérez, V.; Vila-Crespo, J. Evaluating the Influence of Simultaneous Inoculation of SiO2-Alginate Encapsulated Bacteria and Yeasts on Volatiles, Amino Acids, Biogenic Amines and Sensory Profile of Red Wine with Lysozyme Addition. Food Chem. 2020, 327, 126920. [CrossRef]

159. Smit, A.Y.; Engelbrecht, L.; du Toit, M. Managing Your Wine Fermentation to Reduce the Risk of Biogenic Amine Formation. Front. Microbiol. 2012, 3. [CrossRef] [PubMed]

160. Brizuela, N.S.; Bravo-Ferrada, B.M.; La Hens, D.V.; Hollmann, A.; Delfederico, L.; Caballero, A.; Tymczyszyn, E.E.; Semorile, L. Comparative Vinification Assays with Selected Patagonian Strains of Oenococcus oeni and Lactobacillus plantarum. LWT 2017, 77, 348-355. [CrossRef]

161. Russo, P.; Englezos, V.; Capozzi, V.; Pollon, M.; Río Segade, S.; Rantsiou, K.; Spano, G.; Cocolin, L. Effect of Mixed Fermentations with Starmerella bacillaris and Saccharomyces cerevisiae on Management of Malolactic Fermentation. Food Res. Int. 2020, $134,109246$. [CrossRef] [PubMed]

162. Nardi, T.; Panero, L.; Petrozziello, M.; Guaita, M.; Tsolakis, C.; Cassino, C.; Vagnoli, P.; Bosso, A. Managing Wine Quality Using Torulaspora delbrueckii and Oenococcus oeni Starters in Mixed Fermentations of a Red Barbera Wine. Eur. Food Res. Technol. 2019, 245, 293-307. [CrossRef]

163. Capozzi, V.; Berbegal, C.; Tufariello, M.; Grieco, F.; Spano, G.; Grieco, F. Impact of Co-Inoculation of Saccharomyces cerevisiae, Hanseniaspora uvarum and Oenococcus oeni Autochthonous Strains in Controlled Multi Starter Grape Must Fermentations. LWT 2019, 109, 241-249. [CrossRef]

164. Tempère, S.; Marchal, A.; Barbe, J.-C.; Bely, M.; Masneuf-Pomarede, I.; Marullo, P.; Albertin, W. The Complexity of Wine: Clarifying the Role of Microorganisms. Appl. Microbiol. Biotechnol. 2018, 102, 3995-4007. [CrossRef] [PubMed]

165. Sipsas, V.; Kolokythas, G.; Kourkoutas, Y.; Plessas, S.; Nedovic, V.A.; Kanellaki, M. Comparative Study of Batch and Continuous Multi-Stage Fixed-Bed Tower (MFBT) Bioreactor during Wine-Making Using Freeze-Dried Immobilized Cells. J. Food Eng. 2009, 90, 495-503. [CrossRef]

166. Bleve, G.; Lezzi, C.; Chiriatti, M.A.; D’Ostuni, I.; Tristezza, M.; Venere, D.D.; Sergio, L.; Mita, G.; Grieco, F. Selection of NonConventional Yeasts and Their Use in Immobilized Form for the Bioremediation of Olive Oil Mill Wastewaters. Bioresour. Technol. 2011, 102, 982-989. [CrossRef]

167. Simó, G.; Vila-Crespo, J.; Fernández-Fernández, E.; Ruipérez, V.; Rodríguez-Nogales, J.M. Highly Efficient Malolactic Fermentation of Red Wine Using Encapsulated Bacteria in a Robust Biocomposite of Silica-Alginate. J. Agric. Food Chem. 2017, 65, 5188-5197. [CrossRef] [PubMed]

168. Genisheva, Z.; Mussatto, S.I.; Oliveira, J.M.; Teixeira, J.A. Malolactic Fermentation of Wines with Immobilised Lactic Acid Bacteria-Influence of Concentration, Type of Support Material and Storage Conditions. Food Chem. 2013, 138, $1510-1514$. [CrossRef] [PubMed]

169. Bleve, G.; Tufariello, M.; Vetrano, C.; Mita, G.; Grieco, F. Simultaneous Alcoholic and Malolactic Fermentations by Saccharomyces cerevisiae and Oenococcus oeni Cells Co-Immobilized in Alginate Beads. Front. Microbiol. 2016, 7. [CrossRef] [PubMed]

170. Ruiz, P.; Izquierdo, P.M.; Seseña, S.; Palop, M.L. Selection of Autochthonous Oenococcus oeni Strains According to Their Oenological Properties and Vinification Results. Int. J. Food Microbiol. 2010, 137, 230-235. [CrossRef] [PubMed] 